\title{
Characterization of Gnrh/Gnih elements in the olfacto-retinal system and ovary during zebrafish ovarian maturation
}

\author{
Sheryll Corchuelo a, Emanuel R.M. Martinez ${ }^{\mathrm{d}}$, Arno J. Butzge ${ }^{\mathrm{a}, \mathrm{d}}$, Lucas B. Doretto ${ }^{\mathrm{d}}$,

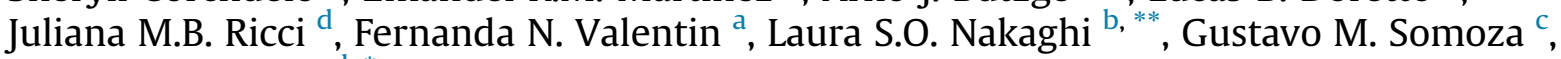 \\ Rafael H. Nóbrega d, * \\ a Aquaculture Center of São Paulo State University (CAUNESP), Jaboticabal, São Paulo, Brazil \\ ${ }^{\mathrm{b}}$ Department of Animal Morphology and Physiology, São Paulo State University (UNESP), Jaboticabal, São Paulo, Brazil \\ ${ }^{c}$ Laboratorio de Ictiofisiología y Acuicultura, Instituto de Investigaciones Biotecnológicas-Instituto Tecnológico de Chascomús (CONICET-UNSAM), \\ Chascomús, Argentina \\ ${ }^{\mathrm{d}}$ Reproductive and Molecular Biology Group, Department of Morphology, Institute of Bioscience of Botucatu, São Paulo State University, Botucatu, São \\ Paulo, Brazil
}

\section{A R T I C L E I N F O}

\section{Article history:}

Received 2 December 2016

Received in revised form

15 March 2017

Accepted 4 April 2017

Available online 8 April 2017

\section{Keywords:}

Sensorial systems

Gnrh

Gnih

Olfactory bulb

Ovarian maturation

Zebrafish

\begin{abstract}
A B S T R A C T
Gonadotropin releasing hormone (GnRH) is one of the key players of brain-pituitary-gonad axis, exerting overall control over vertebrate reproduction. In zebrafish, two variants were characterized and named as Gnrh2 and Gnrh3. In this species, Gnrh3, the hypohysiotropic form, is expressed by neurons of the olfactory-retinal system, where it is related with food detection, intra/interspecific recognition, visual acuity and retinal processing modulation. Previous studies have reported the presence of Gnrh receptors in the zebrafish retina, but not yet in the zebrafish olfactory epithelium. The current study analyzed the presence of gnrh2 and gnrh3, their receptors (gnrhr 1,2,3 and 4) and gnih (gonadotropin inhibitory hormone) transcripts, as well as the Gnrh3 protein in the olfactory epithelium (OE), olfactory bulb (OB), retina and ovary during zebrafish ovarian maturation. We found an increase of gnrh receptors transcripts in the $\mathrm{OE}$ at the final stages of ovarian maturation. In the $\mathrm{OE}$, Gnrh3 protein was detected in the olfactory receptor neurons cilia and in the olfactory nerve fibers. Interestingly, in the $\mathrm{OB}$, we found an inverse expression pattern between gnih and gnrh3. In the retina, gnrhr4 mRNA was found in the nuclei of amacrine, bipolar, and ganglion cells next to Gnrh3 positive fibers. In the ovary, gnrh3, gnrhr2 and gnrhr4 transcripts were found in perinucleolar oocytes, while gnih in oocytes at the cortical alveolus stage. Our results suggested that Gnrh/Gnih elements are involved in the neuromodulation of the sensorial system particularly at the final stages of maturation, playing also a paracrine role in the ovary.
\end{abstract}

(c) 2017 Elsevier B.V. All rights reserved.

\section{Introduction}

In vertebrates, gonadal maturation is regulated by the hypothalamic-pituitary-gonadal (HPG) axis (Chen and Fernald, 2008; Sower et al., 2009). Gonadotropin-releasing hormone (GnRH) is a key factor in this axis; it is secreted from the hypothalamus and is responsible to stimulate the synthesis and release of Fsh (Follicle-stimulating hormone) and Lh (Luteinizing

\footnotetext{
* Corresponding author.

** Corresponding author.

E-mail addresses: laurankg@yahoo.com.br (L.S.O. Nakaghi), biorhn@yahoo.com. br (R.H. Nóbrega).
}

hormone) from the pituitary gland, which ultimately control gametogenesis and gonadal steroidogenesis (Chen and Fernald, 2008). Since its discovery in mammalian brains (Amoss et al., 1971; Baba et al., 1971), 18 different forms of GnRH variants have been identified in vertebrates (Roch et al., 2014). In general, GnRH is currently classified into three types according to their location and function: type 1 (GnRH1), type 2 (GnRH2) and type 3 (GnRH3) (White and Fernald, 1998; Guilgur et al., 2007). With respect to their function, GnRH1 is associated with gonadotropin secretion (Schwanzel-Fukuda and Pfaff, 1990); GnRH2 appears to be involved in the regulation of sexual and feeding behavior (Volkoff and Peter, 1999; Temple et al., 2003; Matsuda et al., 2008) and GnRH3 is associated with neural mechanisms of sexual behavior (Eisthen et al., 2000; Biju et al., 2003, 2005). In cyprinids, such as Danio 
rerio, two Gnrh forms were described in the brain; Gnrh2 in diencephalon and midbrain, and Gnrh3 in the ventral forebrain (Powell et al., 1996; Abraham et al., 2009).

Several studies have linked GnRH with visual acuity (Maaswinkel and Li, 2003) and olfactory epithelium sensitivity (Kawai et al., 2009) through terminal nerve (NT). The mechanisms by which GnRH modulates olfactory response are not yet defined, but some studies suggested that GnRH is involved on olfactory signal transduction (Kawai et al., 2009), modulating the excitability of the olfactory receptor neurons (ORNs) and increasing its response to odorants (Eisthen et al., 2000; Kawai et al., 2009). In this context, studies in salamanders have localized $\mathrm{GnRH}$ receptors in the olfactory epithelium (OE), indicating a possible role of $\mathrm{GnRH}$ on the olfactory system (Wirsig-Wiechmann and Jennes, 1993; Zhang and Delay, 2007). Also, in zebrafish, recent data showed visual acuity improvement under different olfactory stimuli (Maaswinkel and Li, 2003; Stephenson et al., 2012). Interestingly, Gnrh3 was detected in TN neurons and GnRH receptors in different layers of the retina of different species (Wirsig-Wiechmann and Wiechmann, 2002; Grens et al., 2005; Servili et al., 2012), reinforcing $\mathrm{GnRH}$ as a modulator of the sensorial stimuli. GnRH has also been reported in many extra-hypothalamic mammalian and teleostean tissues including the ovaries (Iwashita and Catt, 1985; Pati and Habibi, 1998; Okubo et al., 1999, 2006; Madigou et al., 2000). In the goldfish ovary, Gnrh is involved in the regulation of follicle development, steroidogenesis, apoptosis and in the maintenance of gonadal synchrony (Andreu-Vieyra and Habibi, 2000).

In the last years, other hypothalamic neuropeptide, gonadotropin inhibitory hormone $(\mathrm{GnIH})$, was discovered. GnIH was originally identified in quails, and is responsible to regulate the synthesis and release of pituitary gonadotropins (Tsutsui et al., 2000). GnIH acts on GnRH neurons and on pituitary cells inhibiting the reproductive system (Tsutsui, 2009; Tsutsui et al., 2012; Parhar et al., 2012; Tsutsui and Ubuka, 2016). In fish, Gnih was found in the olfactory bulb of different species (Ogawa and Parhar, 2014; Biswas et al., 2015; Di Yorio et al., 2016; Paullada-Salmerón et al., 2016) and in the retina (Paullada-Salmerón et al., 2016), however, to the best of our knowledge no reports on Gnih physiological function in these areas have been published. Also, Gnih and its receptors have been described in the gonads of several vertebrates, such as fish, birds, reptiles and mammals (Bentley et al., 2008, 2010; Maddineni et al., 2008; Singh et al., 2008; Qi et al., 2013; Zhang et al., 2010). Also, although not fully explored, recent studies have demonstrated that Gnih inhibited mice follicular development and steroidogenesis (Singh et al., 2011).

In this framework, the aim of this study was to examine the expression and cellular localization of Gnrh (Gnrh2, 3), Gnrh receptors (Gnrh-r1, 2, 3 and 4) and Gnih in the OE, retina, olfactory bulb (OB) and ovary of $D$. rerio. We also evaluated whether Gnrh,
Gnrhr and Gnih in the olfacto-retinal system are linked with reproduction by analyzing their expression levels during the different stages of zebrafish ovarian maturation.

\section{Material and methods}

\subsection{Zebrafish stocks}

Sexually mature $(n=15)$ and immature $(n=40)$ female and male $(\mathrm{n}=10)$ zebrafish ( $D$. rerio) between 4 and 12 months of age were used in the present study. Animal housing and experimentation were consistent with the Brazilian national regulations and UNESP Committee for Ethics and Animal Care and Use in Jaboticabal/Botucatu (São Paulo, Brazil) has approved the protocols (2554/15).

\subsection{Tissue sampling and ovarian histological analysis}

Before sampling, fish were anesthetized (1\% benzocaine), and subsequently their organs/tissues (OE, retina, brain, $\mathrm{OB}$ and ovary) collected, snap frozen in liquid nitrogen and stored at $-80^{\circ} \mathrm{C}$ until RNA isolation. To determine the gonadal maturity and the ovarian stage of each collected animal, part of the ovary was fixed in modified Karnovsky solution (2\% glutaraldehyde and 4\% paraformaldehyde in Sorensen buffer [0.1 M, pH 7.2]) for at least $24 \mathrm{~h}$. Further, samples were processed, embedded in methyl methacrylate (Technovit 7100-Heraeus Kulzer, Wehrheim, Germany) and $3 \mu \mathrm{m}$ thickness sections obtained and stained with toluidine blue according to Leal et al. (2009). Ovaries were classified into four maturation stages: primary growth stage (PG), pre-vitellogenic stage (PV), mid-vitellogenic stage (MV) and late vitellogenic stage (LV) (Fig. 1), according to Wang and Ge (2004).

\subsection{Expression of gnrh and gnih by RT-PCR and $q P C R$}

To evaluate gene expression, samples were snap frozen in liquid nitrogen and stored at $-80^{\circ} \mathrm{C}$ until RNA isolation. $\mathrm{OE}$ and $\mathrm{OB}$ were removed from 36 females, and grouped according to the gonadal stage ( $\mathrm{n}=9$ per reproductive stage), and pooled $(\mathrm{n}=3$ ) for total RNA extraction using PureLink ${ }^{\circledR}$ RNA Mini Kit $\left(\right.$ Ambion $^{\circledR}$ ) following the manufacturer's protocol. For larger organs (brain, retina and gonads), RNA was extracted using Trizol ${ }^{\mathrm{TM}}$ (Invitrogen, USA). For both, DNase treatment using DNase I, RNase-free kit (Invitrogen, Carlsbad, CA, USA) was performed, and subsequently cDNA was synthesized using SuperScript ${ }^{\circledR}$ II Reverse Transcriptase kit (Invitrogen $\mathrm{TM}$, Carlsbad, CA, USA) with random hexamers according to standard protocols (Nóbrega et al., 2010). RT-PCR and qPCR reactions were conducted using specific primers for zebrafish gnrh2, gnrh3, gnrhr1, gnrhr2, gnrhr3, gnrhr4 and gnih (Table S1). Zebrafish
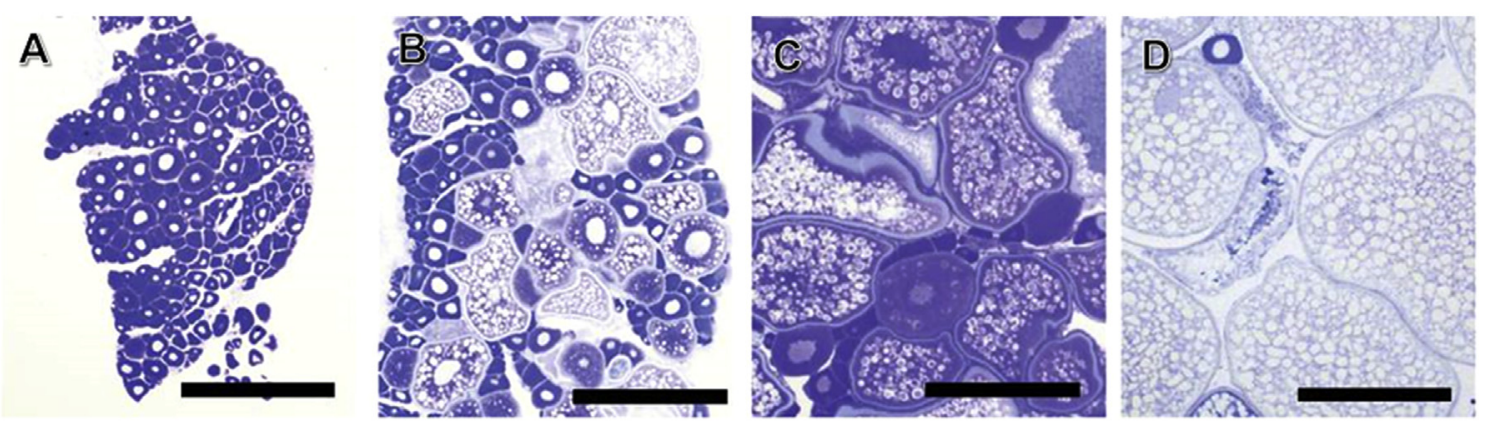

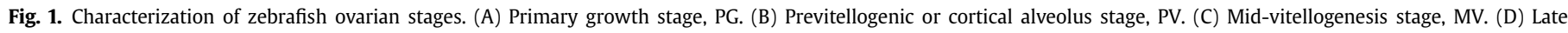
vitellogenesis stage, LV. Scale bars: (A,D) $420 \mu \mathrm{m}$; (B) $630 \mu \mathrm{m}$; (C) $315 \mu \mathrm{m}$. 
$\beta$-actin (NCBI: AF057040.1) (Table S1) was used as endogenous reference gene for RT-PCR reactions, while elongation factor $1 \alpha$ $(e f 1 \alpha)$ and $\beta$-actin were used as housekeeping genes for qPCR.

The RT-PCR products were separated on a $1 \%$ agarose gel and visualized over a UV transilluminator (Fig. 2). Cq (quantification cycle) values for gnrh2, gnrh3, gnrhr1, gnrhr2, gnrhr3, gnrhr4 and gnih were determined in a StepOne system (Life Technologies) using SYBR Green (Invitrogen) and specific primers (Table S1). All qPCR reactions $(20 \mu \mathrm{l})$ used $900 \mathrm{nM}$ for each primer and $300 \mathrm{ng}$ of total RNA. Each reaction was performed in duplicate. Relative gene expression levels were calculated according to the $\Delta \Delta \mathrm{Ct}$ method as described previously (Vischer et al., 2003). Expression levels for each gene were normalized with two endogenous reference genes (see above), and subsequently calibrated to the $\mathrm{Ct}$ average of all samples $(\Delta \Delta \mathrm{Ct})$. For comparative analysis per stage, relative expressions were calibrated to the $\mathrm{Ct}$ average of all target genes from all samples (Figs. S1-4).

\subsection{Localization of gnrh and gnih cellular expression sites by in situ hybridization}

The expression sites of gnrh and gnih in zebrafish OE, retina and gonads were identified by in situ hybridization as described previously (Nóbrega et al., 2015). Digoxigenin-labeled sense and antisense cRNA were synthesized from specific PCR product generated with primers containing T3 or T7 RNA polymerase promoter sequences at 5'-ends (Table S1). The expected PCR product was extracted, purified with Zymoclean DNA recovery kit (Synapse D4001) and transcribed using DIG-UTP (digoxigenin) and RNA T7 polymerase (anti-sense) and T3 (sense) Roche kit (Roche 11758888001). The situ hybridization was performed with adaptations of Thisse and Thisse. (2008). Briefly, tissues were fixed overnight in $4 \%$ phosphate-buffered paraformaldehyde ( $\mathrm{pH} 7.4$ ) in RNase-free conditions, dehydrated, diaphanized, embedded in paraffin (Paraplast ${ }^{\mathbb{R}}$, Sigma) and sectioned with $5 \mu \mathrm{m}$ thickness. Subsequently, the slides were rehydrated and washed with PBT (Tris buffer phosphate, $\mathrm{pH}$ : 7.4) and TrisHCl buffer (0.05 M, pH: 7.5). The material was treated with proteinase $\mathrm{K}(20 \mu \mathrm{g} / \mathrm{ml})$ at $37^{\circ} \mathrm{C}$ for $20 \mathrm{~min}$ and incubated with hybridization solution containing either sense or antisense RNA probe at $70{ }^{\circ} \mathrm{C}$ overnight. The slides were incubated with anti-DIG-AP primary antibody (anti-digoxigeninalkaline phosphatase conjugated) diluted 1:2000 in the same blocking solution at $4{ }^{\circ} \mathrm{C}$ overnight. Tissues were washed and incubated with staining solution NBT/BCIP (nitro-blue tetrazolium chloride/5-bromo-4-chloro-3'-indolyphosphate p-toluidine salt) (Thermo Scientific Pierce), and the slides were photographed using

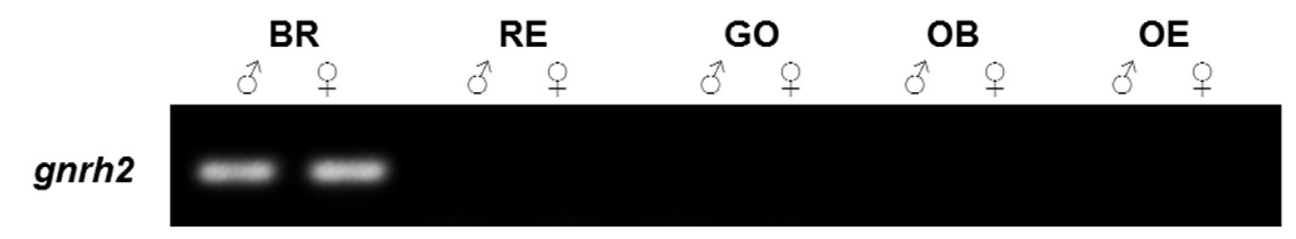

gnrh3

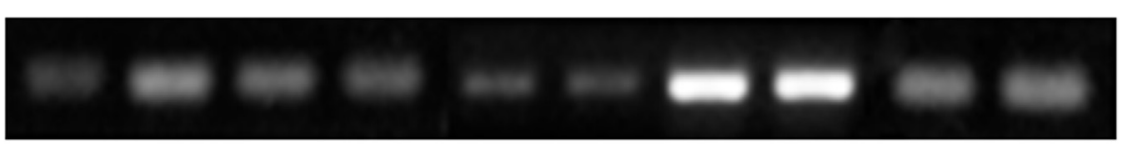

gnrhr1

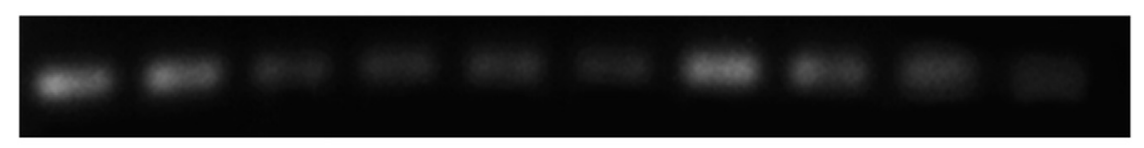

gnrhr2

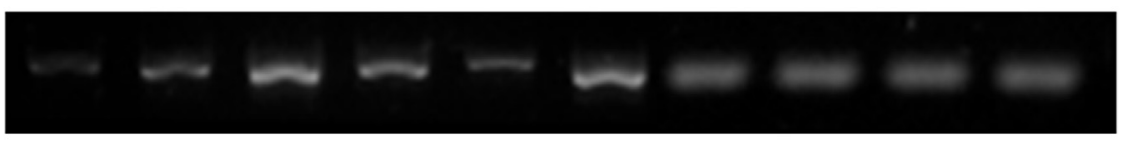

gnrhr3

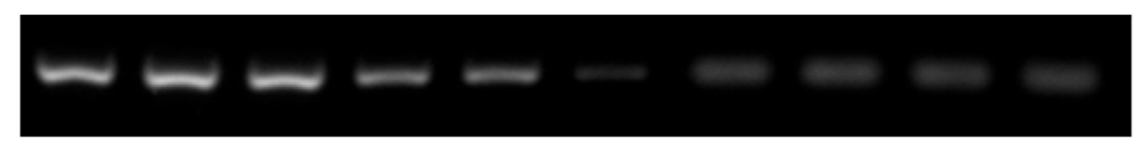

gnrhr4

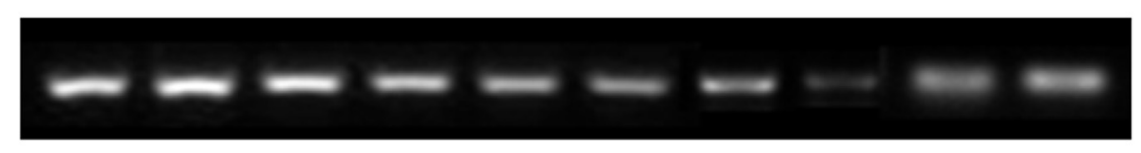

gnih

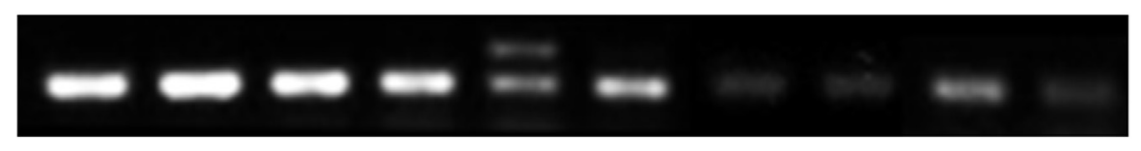

$\beta$-actin

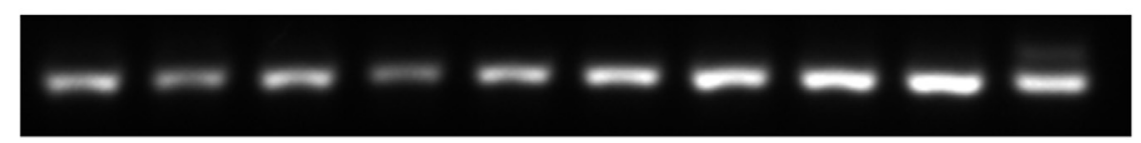

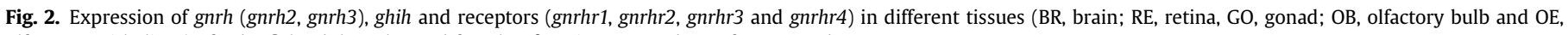
olfactory epithelium) of zebrafish adult males and females. $\beta$-actin was used as reference endogenous gene. 
the microscope Leica DMI 4000B.

\subsection{Localization of GnRH3 cellular sites by immunohistochemistry}

Immunohistochemistry reactions were performed to identify GnRH3 cellular sites in different organs of zebrafish (OE, retina and gonads), as described previously by Gomes et al. (2013). Tissues were fixed in Bouin solution for $24 \mathrm{~h}$ at $4{ }^{\circ} \mathrm{C}$, dehydrated, diaphanized, embedded in paraffin (Paraplast ${ }^{\mathbb{B}}$, Sigma), and sectioned with $5 \mu \mathrm{m}$ thick. Sections were dewaxed, rehydrated and submitted to hydrogen peroxide $0.3 \%$ in PBS (phosphate buffered saline, $\mathrm{pH}$ : 7.4) for $5 \mathrm{~min}$ to block endogenous peroxidase. After washing with PBS, blocking of nonspecific sites was done with normal goat serum $5 \%$. Subsequently, sections were incubated overnight at $4{ }^{\circ} \mathrm{C}$ with primary antibody anti-Gnrh3 (salmon) BB8 (1: 700), kindly provided by Dr Olivier Kah (University of Rennes, France). After the incubation period, sections were washed in PBS and incubated for $30 \mathrm{~min}$ in the polymer-HRP EasyLink One (EasyPath). Finally, slides were stained with DAB (3,3-diaminobenzidine, Sigma Chemical) and counterstained with Harris hematoxylin. As negative control, primary antibody was preabsorbed (1:5) with synthetic GnRH analog $(1 \mu \mathrm{M})\left(\right.$ CONCEPTAL $^{\circledR}$, Intervet) diluted in PBS. The primary antibody was omitted in some of the immunohistochemical reactions.

\subsection{Statistical analyses}

Values were presented as mean \pm SEM. Differences between two groups were identified using paired or unpaired Student's t-test, and for three or more groups ANOVA followed by the
Student-Newman-Keuls test. Graph Pad Prism 4.0 software (Graph Pad Software, Inc., San Diego, CA, USA, http://www. graphpad.com) was used for all statistical analyzes. Significance level (p) was fixed at 0.05 .

\section{Results}

3.1. Cellular localization of Gnrh, Gnrh receptors and Gnih in the zebrafish olfactory-retinal system and ovary

In the zebrafish $\mathrm{OE}$, immunoreactive-Gnrh3 (ir-Gnrh3) was found in the cytoplasm of the olfactory receptor neurons (Fig. 3A,C), in particular at the apical surface and in the dendritic processes of the neurons (Fig. 3E). Moreover, ir-Gnrh3 fibers were also detected in the connective tissue (lamina propria), located beneath the $\mathrm{OE}$ (Fig. 3A). Fascicles of nerve fibers either associated with blood vessels (Fig. 3F) or between fibers towards the OB (Fig. 3G) also exhibited ir-Gnrh3. Control with preabsorbed antibody confirmed the specificity of the immunohistochemistry reactions (Fig. 3B,D). No signals were detected for any of the in situ cRNA probes used (gnrh2, gnrh3, gnrhr1,2,3,4 and gnih) (Data not shown).

In the zebrafish retina, ir-Gnrh3 was observed mainly in fibers distributed close to the outer nuclear layer (ONL), in the outer and inner plexiform layers (OPL, IPL) and running along the ganglion cell layer (GCL) (Fig. 4A). No labeling was detected in the preabsorbed control (Fig. 4B). No signals were detected for any of the following in situ cRNA probes gnrh2, gnrh3, gnrhr1,2,3 and gnih, with the exception of gnrhr4. gnrhr4 transcripts observed in the photoreceptor cells of the outer nuclear layer (ONL), in bipolar and amacrine cells of the inner nuclear layer (INL), and in the ganglion
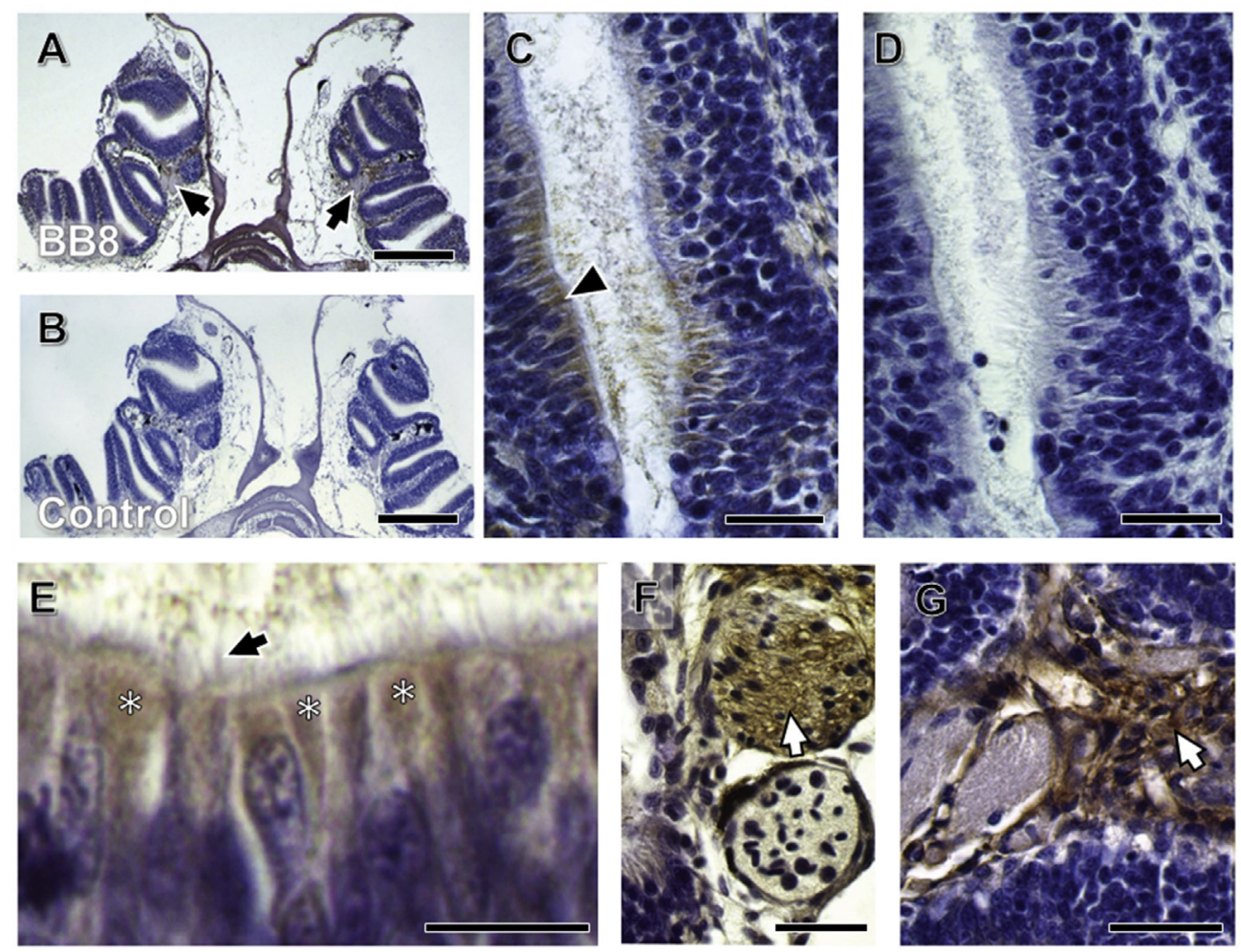

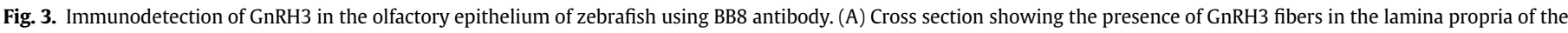

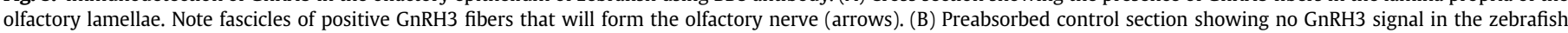

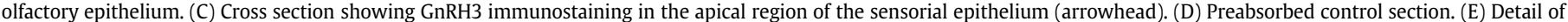

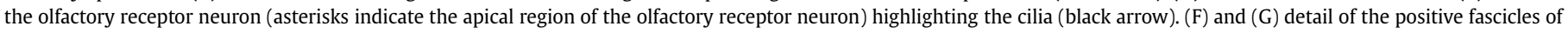
GnRH3 fibers (white arrows) located between the olfactory lamellae. Scale bars: (A-B) $250 \mu \mathrm{m},(\mathrm{C}-\mathrm{D}, \mathrm{F}-\mathrm{G}) 25 \mu \mathrm{m}$; (E) $10 \mu \mathrm{m}$. 

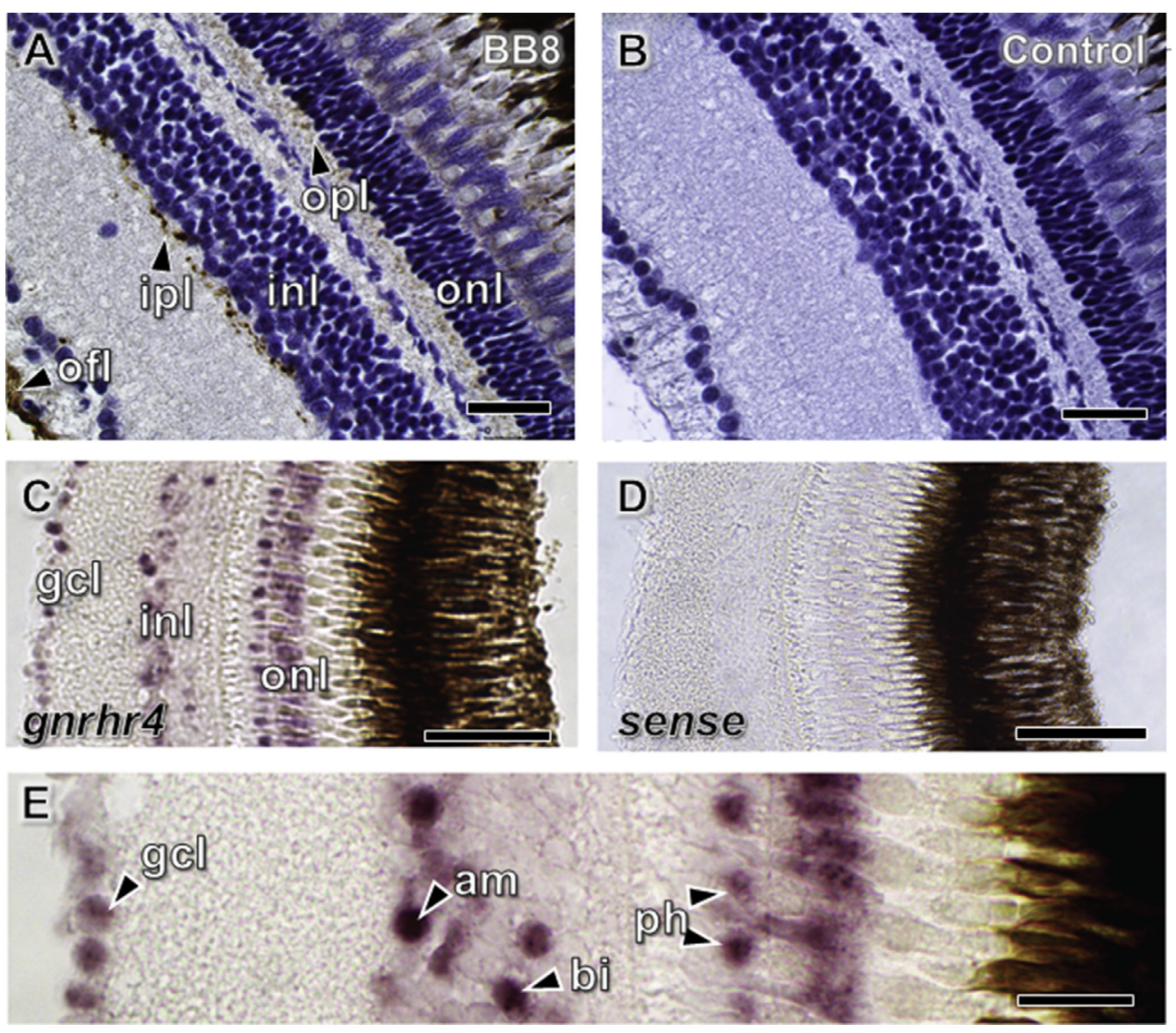

Fig. 4. Immunodetection of GnRH3 and distribution of gnrhr4 receptor mRNA (in situ hybridization - ISH) in the zebrafish retina. (A) GnRH3 immunostaining using BB8 antibody; arrowheads show GnRH3 positive fibers in the inner plexiform layer (ipl), outer plexiform layer (opl) and optic nerve fiber layer (ofl). The inner nuclear layer (inl) is also indicated. (B) Preabsorbed control section. (C) Cross section showing gnrhr4 mRNA in the outer nuclear layer (onl), inner nuclear layer (inl) and ganglion cell layer (gcl) when tissues were incubated with anti-sense RNA probes (T7). (D) ISH control; tissue was incubated with sense riboprobes (T3). (E) Detail of the gnrhr4 transcripts expression sites in the nuclei of photoreceptors (ph), amacrine (am), bipolar (bi) and ganglion cell layer (glc). Scale bars: (A-C, F) $25 \mu \mathrm{m}$; (D-E) $50 \mu \mathrm{m}$.

cells of the ganglion cell layer (GCL) (Fig. 4C, E). No signal was detected when using sense gnrhr4 cRNA probes (Fig. 4D).

In the zebrafish ovary, primary growth (PG) and previtellogenic (PV) (cortical alveolus stage) oocytes were the only ir-Gnrh3 structures (Fig. 5A and B). Interestingly, ir-Gnrh3 was stronger in the cytoplasm of PG oocytes (perinucleolar oocytes) when compared to PV oocytes (cortical alveolus stage) (Fig. 5A and B). In situ hybridization showed Gnrh receptor transcripts, gnrhr2 and gnrhr4, expressed in the cytoplasm and nucleus of PG oocytes (Fig. 5H, I, L). As oocytes reached advanced vitellogenic stages, in situ signals for these receptors decreased, being often restricted to the nucleus and small regions of the cytoplasm (Fig. $5 \mathrm{H}$ ). In addition, gnrhr4 transcripts were also detected in follicular cells and zona radiata of the vitellogenic oocytes (Fig. 4K). With respect to gnih, expression sites for this transcript were found in the PV oocytes particularly in the cortical vesicles (cortical alveoli) (Fig. 5D-E). Interestingly, gnih was also expressed in the follicular cells as well as in the zona radiata of the vitellogenic oocytes (Fig. 5F).

\subsection{Expression of gnrh, gnrh receptors and gnih in the olfactory-} retinal system and ovary during adult zebrafish ovarian maturation

\subsubsection{Olfactory epithelium (OE)}

During the different reproductive stages [primary growth stage (PG), pre-vitellogenic stage (PV), mid-vitellogenic stage (MV) and late-vitellogenic stage (LV)], gnrh2 levels in the OE were significantly higher in the MV stage (Fig. 6A), while gnrh3 was found to decrease only in the PV stage (Fig. 6B). gnih levels remained constant with significantly lower levels in the PV stage (Fig. 6C). All Gnrh receptors (gnrhr1, gnrhr2, gnrhr3 and gnrhr4) were highly expressed in the $\mathrm{OE}$ in later stages of ovarian maturation (MV and LV stages) when compared to earlier ones (PG and PV stages) (Fig. 6D-G). Comparative analysis showed that gnih was more abundant than gnrh2 and gnrh3 during all stages (Fig. S1), while gnrhr3 is the most expressed receptor in the $\mathrm{OE}$, with exception in the PV stage (Fig. S1).

\subsubsection{Olfactory bulb $(O B)$}

During ovarian maturation, gnrh2 transcripts progressively increased from early (PV and MV) to late vitellogenesis (LV) (Fig. 7A). On the other hand, gnrh3 showed an increase in the PV stage (early stage of vitellogenesis) (Fig. 7B). At the same stage, gnih was significantly suppressed (Fig. 7C). Analysis of Gnrh receptors showed constant and stable expression along the ovarian cycle, but gnrhr1 and gnrhr4 decreased in MV stage and gnrhr2 and gnrhr3 in the PV stage (Fig. 7D,G). Comparative analysis showed that gnih and gnrh3 were the most abundant transcripts in the OB (Fig. S2). Interestingly, an inverse correlation is seen between gnhi and gnrh3; when gnrh3 levels were high, gnhi mRNA was very low (Fig. S3). Among receptors, gnrhr3 is the most expressed in the OB, followed by gnrhr4 (Fig. S2). 

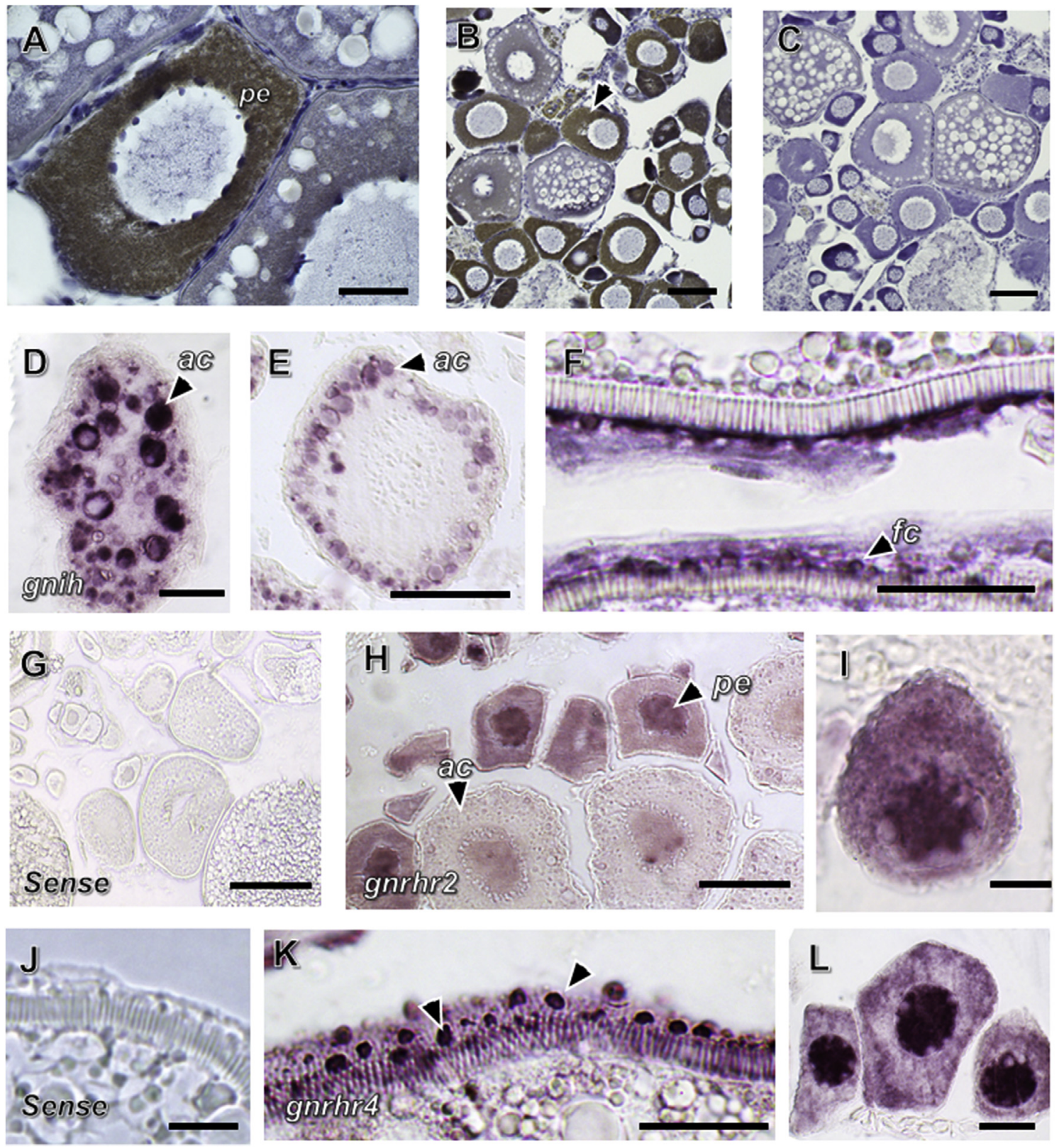

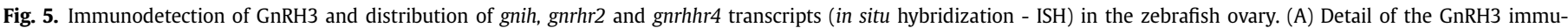

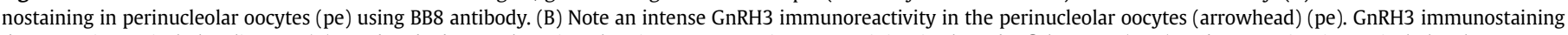

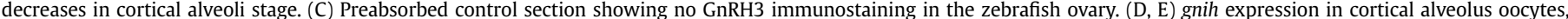

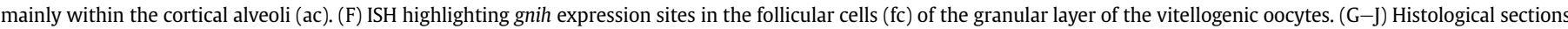

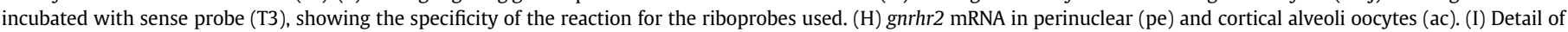

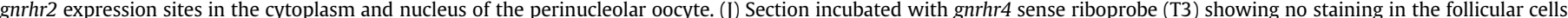

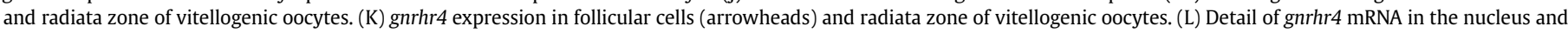
cytoplasm of perinucleolar oocytes. Scale bars: (A, D, F, K-L) $25 \mu \mathrm{m}$; (B-ck, H) $100 \mu \mathrm{m}$; (B-C, E, H) $100 \mu \mathrm{m}$; (G) $250 \mu \mathrm{m}$; (I) $15 \mu \mathrm{m}$.

\subsubsection{Retina}

gnrh2 and gnrh3 remained constant in the retina during all ovarian stages (Fig. 8A and B). The same pattern was observed for gnih, although their levels were reduced in the LV stage compared to PG (Fig. 8C). No expression changes were detected for gnrhr2 and gnrhr3, while gnrhr1 and gnrhr4 showed higher levels at PG stage (Fig. 8D-G). Comparatively, gnrh3, gnrhr2, gnrhr3 and gnrhr4 were the most expressed components in the retina during all stages of ovarian maturation (Fig. S3).

\subsubsection{Ovary}

No significant changes were detected in gene expression levels for ovarian gnrh2 and gnrh3 during the different stages of gonadal maturation (Fig. 9A and B). On the other hand, gnih was highly expressed in PG stage, but suppressed as ovaries started to mature (PV, MV, LV) (Fig. 9C). For Gnrh receptors, gnrhr1 showed variable but not significant levels during ovarian maturation (Fig. 9D); gnrhr2 and gnrhr3 presented higher expression in PG followed by a significant decrease in later stages (PV, MV LV) (Fig. 9E and F); and 


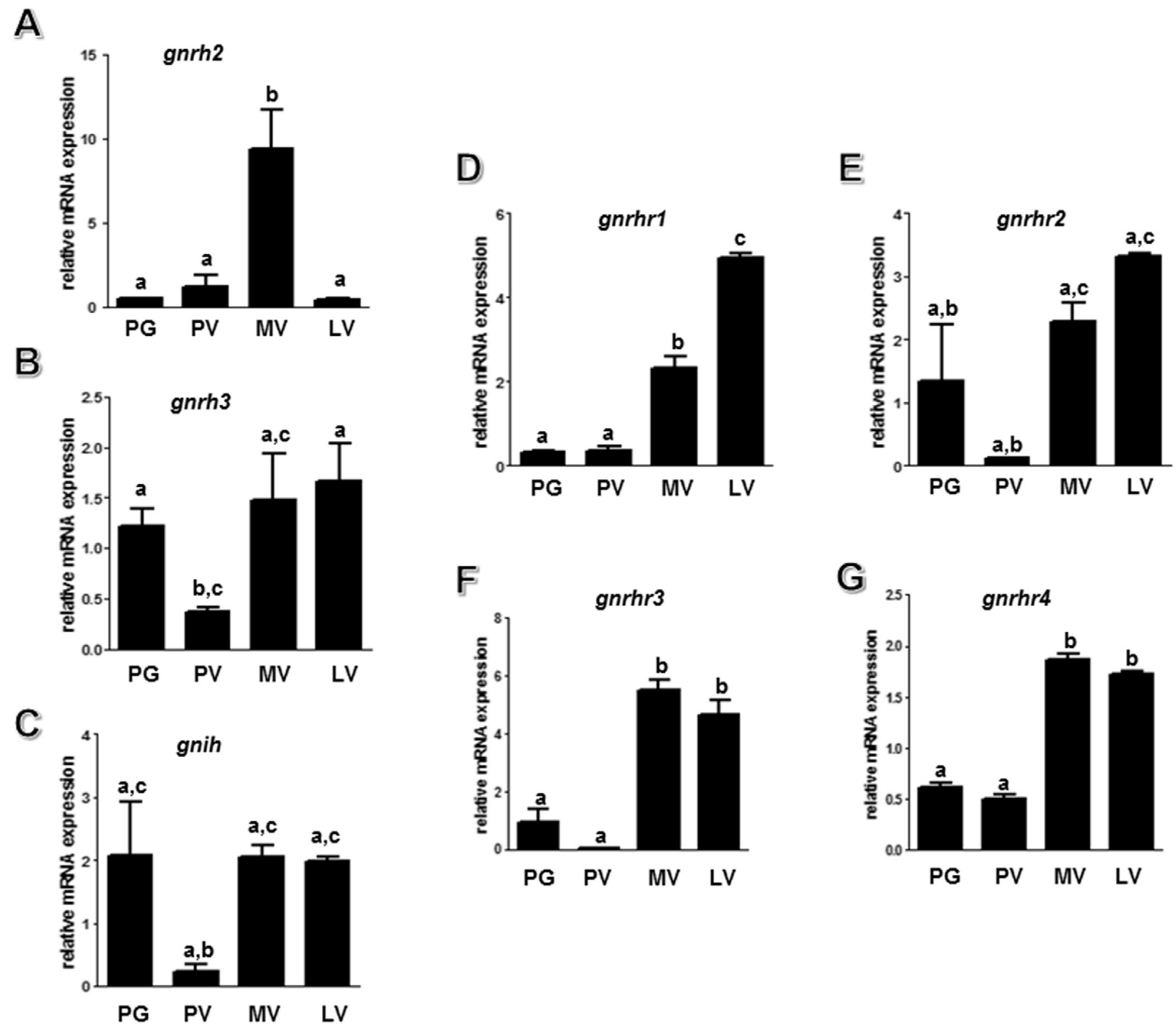

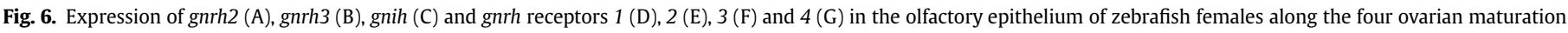

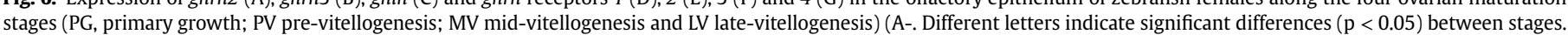

finally, gnrhr4 which decreased gradually along ovarian maturation (Fig. 9G). gnih is more expressed in the ovaries when compared to the other ligands (gnrh3 and gnrh2) (Fig. S4). For the receptors, expression analysis revealed higher levels of gnrhr2 and gnrhr3 during all maturational stages (Fig. S4).

\section{Discussion}

\subsection{Olfactory epithelium (OE)}

This work characterized Gnrh and Gnih elements in the zebrafish OE. In this organ, ir-Gnrh3 was found in the olfactory receptor neurons (ORN) mainly in the apical cytoplasm and cilia of these cells, and also in the fibers of the olfactory nerve, as already described in other teleost species (Subhedar and Krishna, 1988; Biju et al., 2003, 2005; Kawai et al., 2009). The presence of ir-Gnrh3 in these structures suggested a role of this neuropeptide in zebrafish olfactory signal transduction and transmission. This fact is supported by recent studies showing a potential role of Gnrh on olfactory signal transduction by modulating ORN excitability to specific odorant molecules (Eisthen et al., 2000; Kawai et al., 2009). In this context, we speculated whether Gnrh may integrate and modulate the olfactory-retinal system during zebrafish reproduction. For that, we evaluated OE expression levels of gnrh, gnrh receptors and gnih in different stages of ovarian maturation. Interestingly, both ligands (gnrh3 and gnih) and receptors (gnrhr1, gnrhr2, gnrhr3 and gnrhr4) showed higher mRNA levels at final stages of ovarian maturation (MV and LV). If we assume that all mRNAs are translated, our data suggested that zebrafish $\mathrm{OE}$ is more receptive/sensitive to Gnrh molecules at the final stages of gonadal maturation. In this context, similar studies in salamanders have shown increased Gnrh-responsiveness in ORN during the breeding season (Eisthen et al., 2000; Zhang and Delay, 2007). 


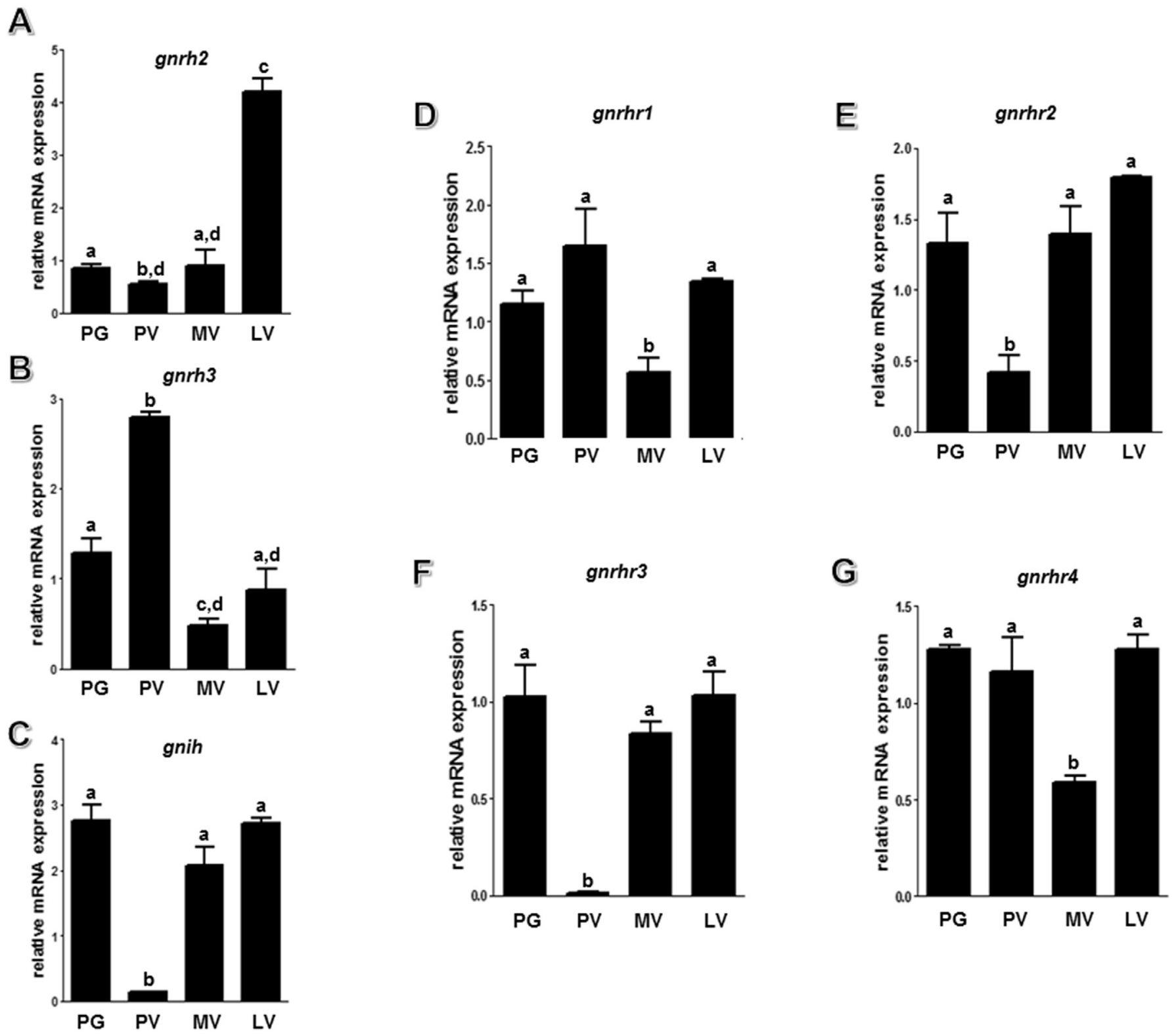

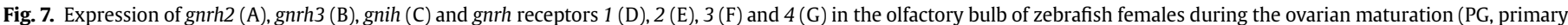
growth; PV pre-vitellogenesis; MV mid-vitellogenesis and LV late-vitellogenesis). Different letters denote significant differences ( $\mathrm{p}<0.05)$ between stages.

\subsection{Olfactory bulb $(O B)$}

In the $\mathrm{OB}$, gnrh3 and gnih were the most expressed transcripts. In this work, we reported an inverse expression pattern between gnrh3 and gnih transcripts in the OB during the zebrafish ovarian maturation. Interestingly, Gnih and Gnrh3 are also neuroanatomically related; Gnih-producing cell bodies are located in the terminal nerve ganglia where Gnrh3 neurons are clustered, as described previously (Sawada et al., 2002; Di Yorio et al., 2016; PaulladaSalmerón et al., 2016). Considering that Gnih might regulate Gnrh secretion in zebrafish (Zhang et al., 2010), it is also possible that Gnih may down-regulate gnrh3 expression in the zebrafish OB. To assess the functional role of Gnih in the OB and demonstrate a link with the ovarian maturation as reported in this work, a pharmacological administration of recombinant zebrafish (rzf) Gnih in females at PV stage was carried out as described in the Supplemental
Material. Our results showed that gnrh3 expression levels did not change after $8 \mathrm{~h}$ in vivo injection or $12 \mathrm{~h}$ in vitro incubation with rzf Gnih (Supplemental Material). Therefore, gnrh3 is not modulated by Gnih and the inverse expression of gnrh3 and gnih might be attributed to other regulatory mechanisms in the OB.

Although Gnrh2 is the most conserved Gnrh, the role of this variant is not yet totally understood. Different studies have shown that Gnrh2 stimulates sexual behavior in females of mammals (Barnett et al., 2006), birds (Maney et al., 1997) and fish (Volkoff and Peter, 1999). In zebrafish, Gnrh2 is also involved in the inhibition of food intake (Nishiguchi et al., 2012) and Gnrh2 fibers are projected into the olfactory bulbs (Xia et al., 2014). In this study, we found increased mRNA levels for gnrh2 in the OB of mature females (final stages of ovarian maturation), suggesting that Gnrh2 may play a role in the zebrafish reproduction/breeding at the OB level, but more studies are needed to unveil the role of Gnrh2 in this species. 


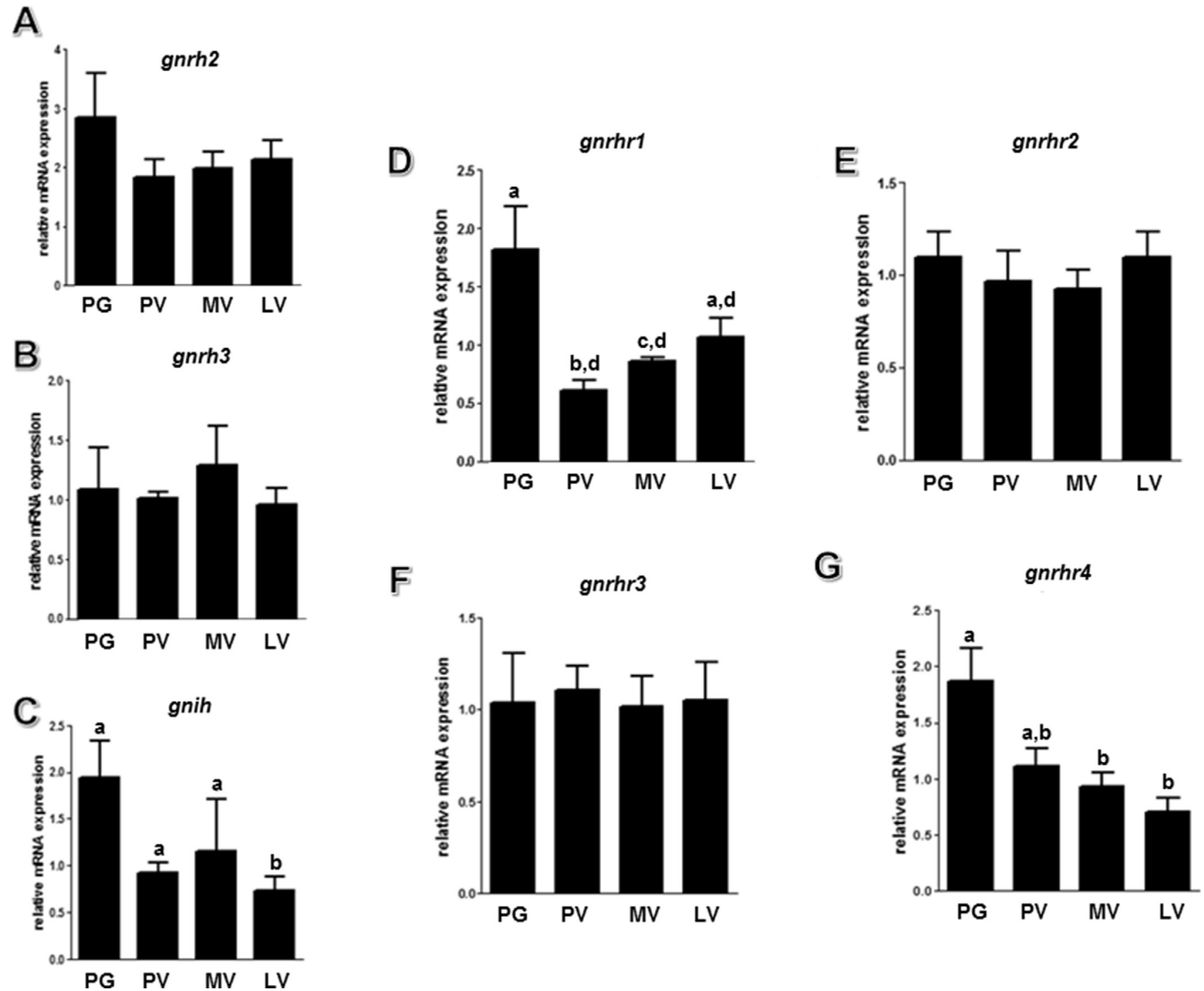

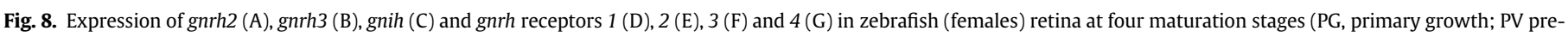
vitellogenesis; MV mid-vitellogenesis and LV late-vitellogenesis). Different letters indicate significant differences $(p<0.05)$ between stages.

Concerning to the Gnrh receptors, two patterns of expression were observed, one for gnrhr1 and gnrhr4 (constant over the stages, decreasing in the MV), and other for gnrhr2 and gnrhr3 (constant over the stages, with reduction in PV). Nevertheless, little is known about the role of these receptors in the zebrafish $\mathrm{OB}$, as well their role over gonadal maturation.

\subsection{Retina}

ir-Gnrh3 fibers were distributed along the three layers of zebrafish retina, as previously described in other teleosts (Münz et al., 1982; Stell et al., 1984; Wirsig-Wiechmann and Wiechmann, 2002; Grens et al., 2005; Maruska and Tricas, 2007). All Gnrh receptors were detected by RT-PCR but only gnrhr4 expression sites were localized by in situ hybridization. In the zebrafish retina, gnrhr4 is expressed in amacrine, bipolar, and ganglion cells. Interestingly, the gnrhr4 expression sites are closely located near to Gnrh3 positive fibers. This interaction also occurs in other teleost species as Astatotilapia burtoni (Grens et al., 2005), Chaetodon multicinctus, Thalassoma duperrey, Abudefduf abdominalis and
Asterropteryx semipunctata (Maruska and Tricas, 2007) and Dicentrarchus labrax (Servili et al., 2012). During ovarian maturation, gnrh2 and gnrh3 remained constant, but gnih decreased in the final stage of vitellogenesis. For the receptors, gnrhr2 and gnrhr3 transcripts remained constant throughout the stages, while gnrhr1 and gnrhr4 decreased at PV and LV. At the moment, we do not know the physiological significance of these observations, as well as the role of Gnih in the retina. However, we do not exclude the role of these neuropeptides as modulators and integrators of the sensorial signal in zebrafish.

\subsection{Ovary}

In teleosts, Gnrh has been found in the ovaries of various species such as goldfish (Pati and Habibi, 1998), Anguilla japonica (Okubo et al., 1999), medaka (Okubo et al., 2006), Oncorhynchus mykiss (Madigou et al., 2000), among others. The present study confirmed the expression of two forms of Gnrh (gnrh2 and gnrh3) in zebrafish ovary, and demonstrated that the Gnrh3 protein is specifically located in the cytoplasm of perinucleolar oocytes, as reported in 


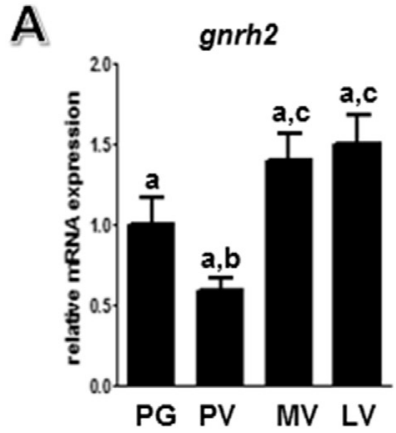

B
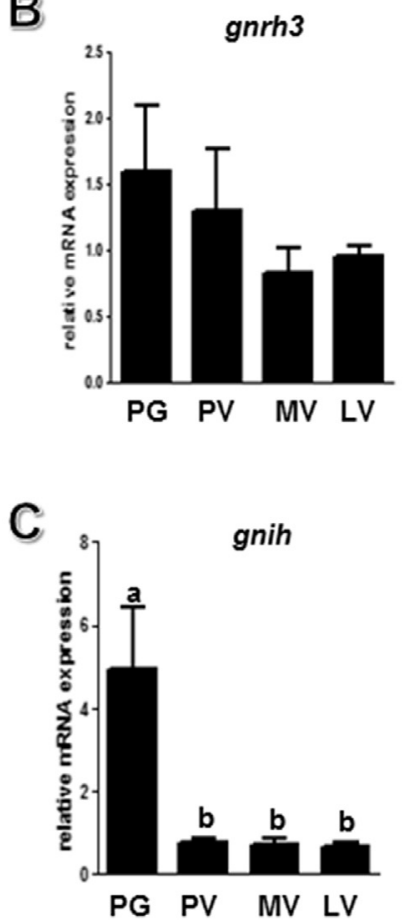
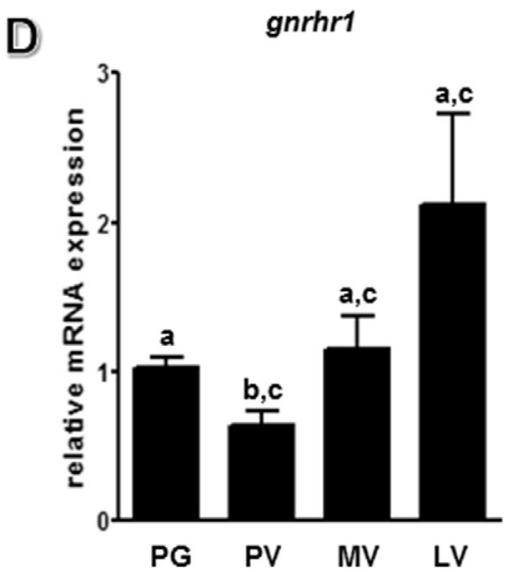

F

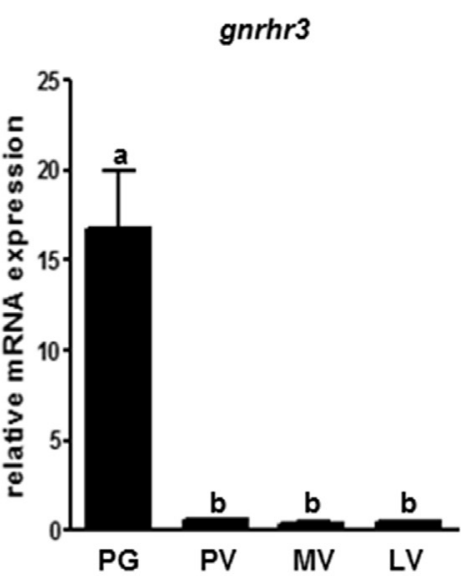

E

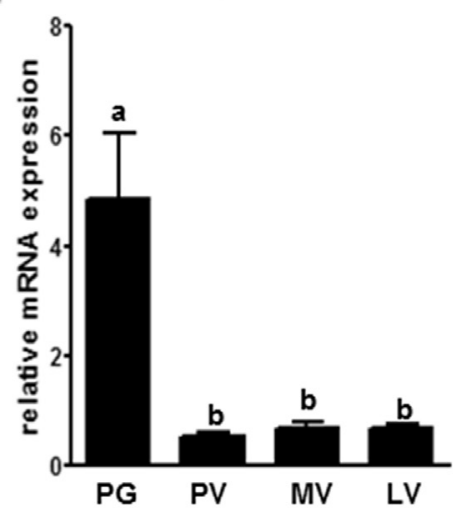

G

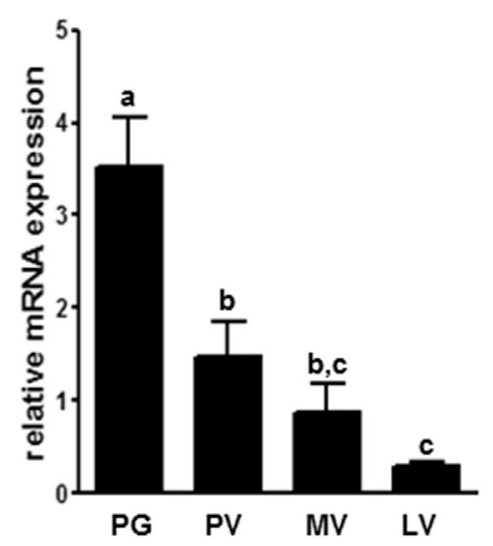

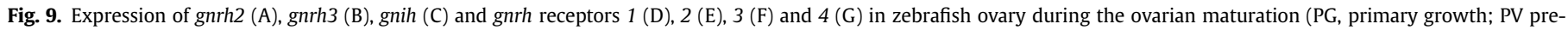
vitellogenesis; MV mid-vitellogenesis and LV late-vitellogenesis). Different letters indicate significant differences $(\mathrm{p}<0.05)$ between stages.

Heteropneustes fossilis (Singh et al., 2007). Moreover, gnrhr2 and gnrhr4 mRNA were also observed in zebrafish perinucleolar oocytes. The co-localization of Gnrh with gnrhr2 and gnrhr4 receptors in perinucleolar oocytes suggests an autocrine/paracrine role of these molecules in the early stages of ovarian maturation in zebrafish. Interestingly, as vitellogenesis progresses, ir-Gnrh3 and gnrhr2 and gnrhr4 mRNA levels decreased. Moreover, gnrhr4 mRNA was detected in the zona radiata and follicular cells of zebrafish vitellogenic oocytes. Similar studies detected gnrh mRNA and its receptors in granulosa cells of humans and mice (Cheng et al., 2002; Kang et al., 2003) and also in the goldfish ovary (Pati and Habibi, 2000). In goldfish, GnRH appears to be involved in the regulation of steroidogenesis, in the induction of apoptosis, as well as in the maintenance of gonadal synchrony (Andreu-Vieyra and Habibi, 2000). Although, no significant differences were observed in the expression levels of gnrh variants, we showed that gnrhr2, gnrhr3, gnrhr4 mRNA decreased significantly during zebrafish vitellogenesis when compared to primary growth oocyte; but gnrhr1 remained constant. These results are in agreement with the in situ hybridization and immunohistochemistry data, which confirmed the expression of Gnrh in the early stages, specifically in perinucleolar oocytes.
The expression of gnih was found to be higher in primary growth ovaries, decreasing significantly during zebrafish vitellogenesis. In situ hybridization data showed gnih transcripts in cortical alveoli stage, specifically in the cortical granules, and also in follicular cells of vitellogenic oocytes. Interestingly, gnih expression did not overlap with ir-Gnrh; while Gnrh3 occurs in perinucleolar oocytes and decreased in cortical alveoli of oocytes, gnih had an inverse expression pattern. Other studies also described Gnih and its receptor in the gonads of zebrafish (Zhang et al., 2010) as in this study and other fish, birds, reptiles and mammals (Bentley et al., 2008; Maddineni et al., 2008; Singh et al., 2008, 2011; Qi et al., 2013). However, the functional implications of gnih expression and its receptor gnihr are widely unexplored in teleosts. Recent studies in mice have demonstrated that Gnih inhibited follicular development and steroidogenesis in the ovary (Singh et al., 2011). This observation is in agreement with our expression data showing decrease of gnih levels as zebrafish ovarian maturation progresses, indicating a possible inhibitory role of Gnih for follicular development. However, more physiological studies are needed to understand the biological role of Gnih in zebrafish ovary.

In summary, this study characterized Gnrh/Gnih elements in the olfacto-retinal system and ovary, highlighting the following 


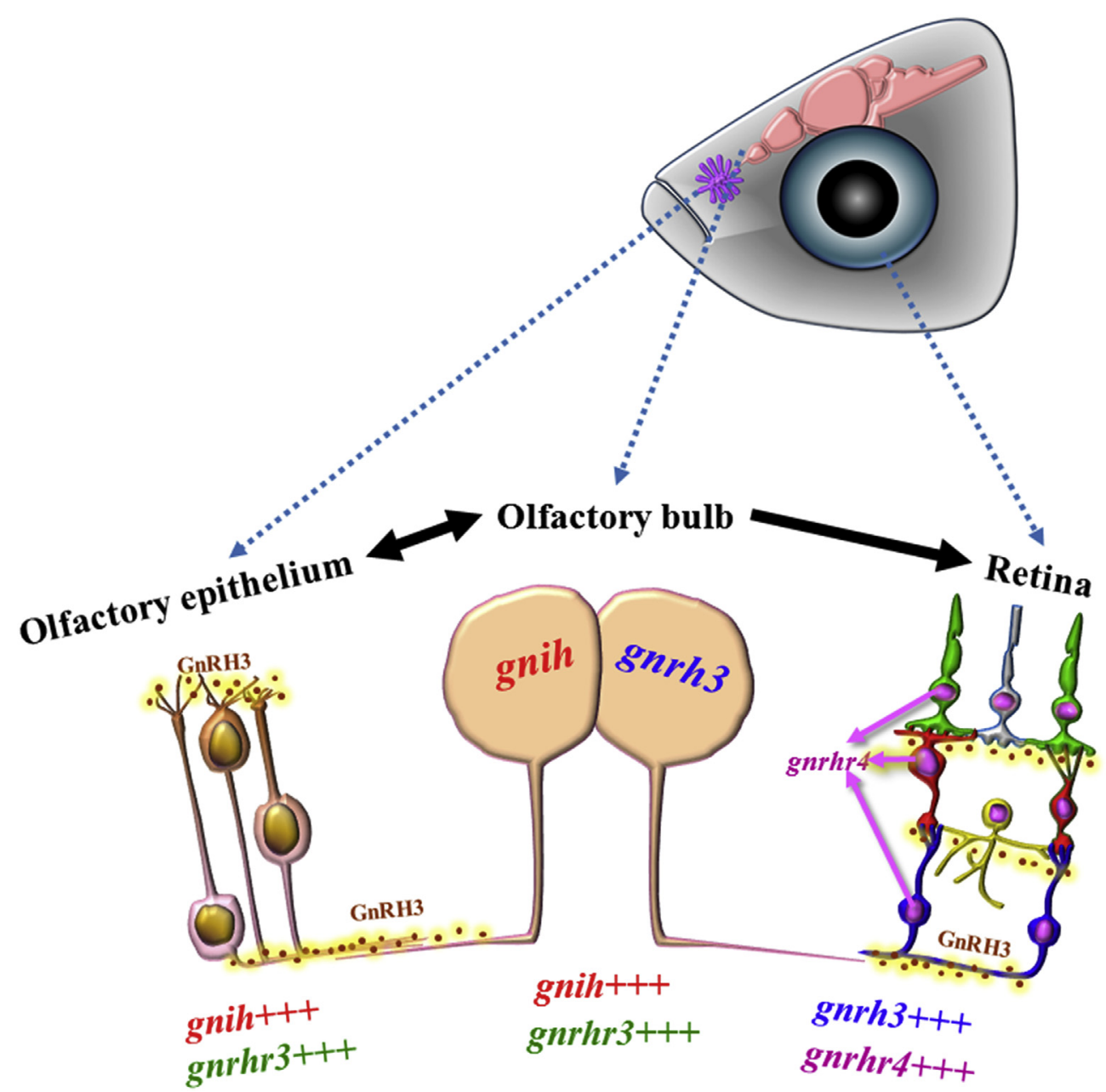

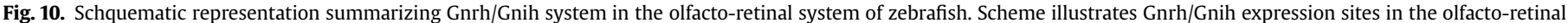
system of zebrafish. $(+++)$ indicates the most expressed ligand or receptor.

findings (Fig. 10): 1) gnrh3 and gnrhr are highly expressed in the OE at final phases of vitellogenesis; 2 ) an inverse relationship between gnih and gnrh3 transcripts in the $\mathrm{OB}$; 3) gnrhr4 expression sites in retina were identified in the nuclei of amacrine, bipolar, and ganglion cells next to ir-Gnrh fibers; 4) Gnrh3 protein is located specifically in the cytoplasm of perinucleolar oocytes. Altogether, these results reinforce Gnrh/Gnih as modulators of the zebrafish sensorial system, establishing a relationship of their expression levels with the reproductive status. Finally, Gnrh/Gnih sites in the zebrafish ovary indicate a local regulation of these peptides, but their role are still not unveiled for zebrafish.

\section{Author contributions}

Conceived and designed the experiments: SC ERMM GMS RHN. Performed the experiments: SC ERMM LBD JMBR Analyzed the data: SC ERMM RHN. Contributed reagents/materials/analysis tools: LSON FNV ERMM RHN AJB JMBR. Wrote the manuscript: SC ERMM GMS LBD RHN.

\section{Acknowledgments}

This study was funded by FAPESP (2014/02481-9; 2012/004236). The authors also thank Dr. Ivan de Godoy Maia, Dr. Danilo Moretti-Ferreira, Dr. Cesar Martins and Dra. Maeli Dal Pai for their assistance help during this work. The authors are also grateful to Aquaculture Center of São Paulo State University (CAUNESP), São Paulo State University (UNESP) and Institute of Biosciences of Botucatu (IBB).

\section{Appendix A. Supplementary data}

Supplementary data related to this article can be found at http:// dx.doi.org/10.1016/j.mce.2017.04.002.

\section{References}

Abraham, E., Palevitch, O., Gothilf, Y., Zohar, Y., 2009. The zebrafish as a model system for forebrain GnRH neuronal development. Gen. Comp. Endocrinol. 164, $151-160$.

Amoss, M., Burgus, R., Blackwell, R., Vale, W., Fellows, R., Guillemin, R., 1971. Purification, amino acid composition and N-terminus of the hypothalamic luteinizing hormone releasing factor (LRF) of ovine origin. Biochem. Bioph. Res. Co. 44, 205-210.

Andreu-Vieyra, C.V., Habibi, H.R., 2000. Factors controlling ovarian apoptosis. Can. J. Physiol. Pharm. 78, 1003-1012.

Baba, Y., Matsuo, H., Schally, A.V., 1971. Structure of the porcine LH- and FSHreleasing hormone. II. Confirmation of the proposed structure by conventional sequential analyses. Biochem. Bioph. Res. Co. 44, 459-463.

Barnett, D.K., Bunnell, T.M., Millar, R.P., Abbott, D.H., 2006. Gonadotropin-releasing hormone II stimulates female sexual behavior in marmoset monkeys. Endocrinology 147, 615-623.

Bentley, G.E., Ubuka, T., McGuire, N.L., Chowdhury, V.S., Morita, Y., Yano, T., Hasunuma, I., Binns, M., Wingfield, J.C., Tsutsui, K., 2008. Gonadotropin-inhibitory hormone and its receptor in the avian reproductive system. Gen. Comp. 
Endocrinol. 156, 34-43.

Bentley, G.E., Tsutsui, K., Kriegsfeld, L.J., 2010. Recent studies of gonadotropininhibitory hormone $(\mathrm{GnIH})$ in the mammalian hypothalamus, pituitary and gonads. Brain Res. 1364, 62-71.

Biju, K.C., Singru, P.S., Schreibman, M.P., Subhedar, N., 2003. Reproduction phaserelated expression of GnRH-like immunoreactivity in the olfactory to the olfactory bulb and in the receptor neurons, their projections nervus terminalis in the female Indian major carp Cirrhinus mrigala (Ham.). Gen. Comp. Endocrinol. 133, 358-367.

Biju, K.C., Gaikwad, A., Sarkar, S., Schreibman, M.P., Subhedar, N., 2005. Ontogeny of GnRH-like immunoreactive neuronal systems in the forebrain of the Indian major carp, Cirrhinus mrigala. Gen. Comp. Endocrinol. 141, 161-171.

Biswas, S., Jadhao, A.G., Pinelli, C., Palande, N.V., Tsutsui, K., 2015. GnIH and GnRH expressions in the central nervous system and pituitary of Indian major carp, Labeo rohita during ontogeny: an immunocytochemical study. Gen. Comp. Endocrinol. 220, 88-92.

Chen, C.C., Fernald, R.D., 2008. GnRH and GnRH receptors: distribution, function and evolution. J. Fish. Biol. 73, 1099-1120.

Cheng, C.K., Yeung, C.M., Chow, B.K.C., Leung, P.C.K., 2002. Characterization of a new upstream GnRH receptor promoter in human ovarian granulosa-luteal cells. Mol. Endocrinol. 16, 1552-1564.

Di Yorio, M.P., Pérez-Sirkin, D.I., Delgadín, T.H., Shimizu, A., Tsutsui, K., Somoza, G.M., Vissio, P.G., 2016. Gonadotropin-inhibitory hormone in the cichlid fish Cichlasoma dimerus: structure, brain distribution and differential effects on the secretion of gonadotropins and growth hormone. J. Neuroendocrinol. 28 http://dx.doi.org/10.1111/jne.12377.

Eisthen, H.L., Delay, R.J., Wirsig-Wiechmann, C.R., Dionne, V.E., 2000. Neuromodulatory effects of gonadotropin releasing hormone on olfactory receptor neurons. J. Neurosci. 20, 3947-3955.

Gomes, C.C., Costa, F.G., Borella, M.I., 2013. Distribution of GnRH in the brain of the freshwater teleost Astyanax altiparanae (Garutti \& Britski, 2000). Micron 52-53, 33-38.

Grens, K.E., Greenwood, A.K., Fernald, R.D., 2005. Two visual processing pathways are targeted by gonadotropin-releasing hormone in the retina. Brain Behav. Evol. 66, 1-9.

Guilgur, L.G., Ortí, G., Strobl-Mazzulla, P.H., Fernandino, J.I., Miranda, L.A., Somoza, G.M., 2007. Characterization of the cDNAs encoding three GnRH forms in the pejerrey fish Odontesthes bonariensis (Atheriniformes) and the evolution of GnRH precursors. J. Mol. Evol. 64, 614-627.

Iwashita, M., Catt, K.J., 1985. Photoaffinity labeling of pituitary and gonadal receptors for gonadotropin-releasing hormone. Endocrinology 117, 738-746.

Kang, S.K., Choi, K.C., Yang, H.S., Leung, P.C.K., 2003. Potential role of gonadotrophinreleasing hormone (GnRH)-I and GnRH-II in the ovary and ovarian cancer. Endocr-Relat. Cancer 10, 169-177.

Kawai, T., Oka, Y., Eisthen, H., 2009. The role of the terminal nerve and GnRH in olfactory system neuromodulation. Zool- Sci. 26, 669-680.

Leal, M.C., de Waal, P.P., Garcia-Lopez, A., Chen, S.X., Bogerd, J., Schulz, R.W., 2009. Zebrafish primary testis tissue culture: an approach to study testis function ex vivo. Gen. Comp. Endocrinol. 162, 134-138.

Maaswinkel, H., Li, L., 2003. Olfactory input increases visual sensitivity in zebrafish: a possible function for the terminal nerve and dopaminergic interplexiform cells. J. Exp. Biol. 206, 2201-2209.

Maddineni, S.R., Ocon-Grove, O.M., Krzysik-Walker, S.M., Hendricks, G.L., Ramachandran, R., 2008. Gonadotropin-inhibitory hormone (GnIH) receptor gene is expressed in the chicken ovary: potential role of $\mathrm{GnIH}$ in follicular maturation. Reproduction 135, 267-274.

Madigou, T., Mañanos-Sanchez, E., Hulshof, S., Anglade, I., Zanuy, S., Kah, O., 2000. Cloning, tissue distribution, and central expression of the gonadotropinreleasing hormone receptor in the rainbow trout (Oncorhynchus mykiss). Biol. Reprod. 63, 1857-1866.

Maney, D.L., Richardson, R.D., Wingfield, J.C., 1997. Central administration of chicken gonadotropin-releasing hormone-II enhances courtship behavior in a female sparrow. Horm. Behav. 32, 11-18.

Maruska, K.P., Tricas, T.C., 2007. Gonadotropin-releasing hormone and receptor distributions in the visual processing regions of four coral reef fishes. Brain Behav. Evol. 70, 40-56.

Matsuda, K., Nakamura, K., Shimakura, S., Miura, T., Kageyama, H., Uchiyama, M., Shioda, S., Ando, H., 2008. Inhibitory effect of chicken gonadotropin-releasing hormone II on food intake in the goldfish, Carassius auratus. Horm. Behav. 54, 83-89.

Münz, H., Claas, B., Stumpf, W.E., Jennes, L., 1982. Centrifugal innervation of the retina by luteinizing hormone releasing hormone (LHRH)-immunoreactive telencephalic neurons in teleostean fishes. Cell Tissue Res. 222, 313-323.

Nishiguchi, R., Azuma, M., Yokobori, E., Uchiyama, M., Matsuda, K., 2012. Gonadotropin-releasing hormone 2 suppresses food intake in the zebrafish, Danio rerio front. Endocrinol 3, 122.

Nóbrega, R.H., Greebe, C.D., van de Kant, H., Bogerd, J., de Franca, L.R., Schulz, R.W., 2010. Spermatogonial stem cell niche and spermatogonial stem cell transplantation in zebrafish. Plos One 5, e12808.

Nóbrega, R.H., Morais, R.D., Crespo, D., de Waal, P.P., de Franca, L.R., Schulz, R.W., Bogerd, J., 2015. Fsh stimulates spermatogonial proliferation and differentiation in zebrafish via Igf3. Endocrinology 156, 3804-3817.

Ogawa, S., Parhar, I.S., 2014. Structural and functional divergence of gonadotropin inhibitory hormone from jawless fish to mammals. Front. Endocrinol. 5, 177.

Okubo, K., Suetake, H., Aida, K., 1999. Expression of two gonadotropin-releasing hormone $(\mathrm{GnRH})$ precursor genes in various tissues of the Japanese eel and evolution of GnRH. Zool. Sci. 16, 471-478.

Okubo, K., Sakai, F., Lau, E.L., Yoshizaki, G., Takeuchi, Y., Naruse, K., Aida, K. Nagahama, Y., 2006. Forebrain gonadotropin-releasing hormone neurona development: insights from transgenic medaka and the relevance to X-linked Kallmann syndrome. Endocrinology 147, 1076-1084.

Parhar, I., Ogawa, S., Kitahashi, T., 2012. RFamide peptides as mediators in environmental control of GnRH neurons. Progr. Neurobiol. 98, 176-196.

Pati, D., Habibi, H.R., 1998. Presence of salmon gonadotropin-releasing hormone $(\mathrm{GnRH})$ and compounds with GnRH-like activity in the ovary of goldfish. Endocrinology 139, 2015-2024.

Pati, D., Habibi, H.R., 2000. Direct action of GnRH variants on goldfish oocyte meiosis and follicular steroidogenesis. Mol. Cell. Endocrinol. 160, 75-88.

Paullada-Salmerón, J.A., Cowan, M., Aliaga-Guerrero, M., Gómez, A., Zanuy, S., Mañanos, E., Muñoz-Cueto, J.A., 2016. LPXRFa peptide system in the European Sea Bass: a molecular and immunohistochemical approach. J. Comp. Neurol. 524, 176-198.

Powell, J.F.F., Krueckel, S.L., Collins, P.M., Sherwood, N.M., 1996. Molecular forms of GnRH in three model fishes: rockfish, medaka and zebrafish. J. Endocrinol. 150, $17-23$.

Qi, X., Zhou, W., Lu, D., Wang, Q., Zhang, H., Li, S., Liu, X., Zhang, Y., Lin, H., 2013. Sexual Dimorphism of steroidogenesis regulated by $\mathrm{GnIH}$ in the goldfish, Carassius auratus. Biol. Reprod. 88, 1-7.

Roch, G.J., Busby, E.R., Sherwood, N.M., 2014. GnRH receptors and peptides: skating backward. Gen. Comp. Endocrinol. 209, 118-134.

Sawada, K., Ukena, K., Satake, H., Iwakoshi, E., Minakata, H., Tsutsui, K., 2002. Novel fish hypothalamic neuropeptide - cloning of a cDNA encoding the precursor polypeptide and identification and localization of the mature peptide. Eur. J. Biochem. 269, 6000-6008.

Schwanzel-Fukuda, M., Pfaff, D.W., 1990. The migration of luteinizing hormonereleasing hormone (LHRH) neurons from the medial alfactory placode into the medial basal forebrain. Experientia 46, 956-962.

Servili, A., Herrera-Perez, P., Kah, O., Munoz-Cueto, J.A., 2012. The retina is a target for GnRH-3 system in the European sea bass, Dicentrarchus labrax. Gen. Comp. Endocrinol. 175, 398-406.

Singh, P., Krishna, A., Sridaran, R., 2007. Localization of gonadotrophin-releasing hormone I, bradykinin and their receptors in the ovaries of non-mammalian vertebrates. Reproduction 133, 969-981.

Singh, P., Krishna, A., Sridaran, R., Tsutsui, K., 2008. Changes in GnRH I, bradykinin and their receptors and $\mathrm{GnIH}$ in the ovary of Calotes versicolor during reproductive cycle. Gen. Comp. Endocrinol. 159, 158-169.

Singh, P., Krishna, A., Tsutsui, K., 2011. Effects of gonadotropin-inhibitory hormone on folliculogenesis and steroidogenesis of cyclic mice. Fert. Steril. 95 1397-1404.

Sower, S.A., Freamat, M., Kavanaugh, S.I., 2009. The origins of the vertebrate hypothalamic-pituitary-gonadal (HPG) and hypothalamic-pituitary-thyroid (HPT) endocrine systems: new insights from lampreys. Gen. Comp. Endocrinol. 161, 20-29.

Stell, W.K., Walker, S.E., Chohan, K.S., Ball, A.K., 1984. The goldfish nervus terminalis: a luteinizing hormone-releasing hormone and molluscan cardioexcitatory peptide immunoreactive olfactoretinal pathway. P. Natl. Acad. Sci.-Biol. 81, 940-944.

Stephenson, J.F., Partridge, J.C., Whitlock, K.E., 2012. Food and conspecific chemical cues modify visual behavior of zebrafish, Danio rerio. Zebrafish 9, 68-73.

Subhedar, N., Krishna, N.S.R., 1988. Immunocytochemical localization of LH-RH in the brain and pituitary of the catfish, Clarias batrachus (Linn. Gen. Comp. Endocrinol. 72, 431-442.

Temple, J.L., Millar, R.P., Rissman, E.F., 2003. An evolutionarily conserved form of gonadotropin-releasing hormone coordinates energy and reproductive behavior. Endocrinology 144, 13-19.

Thisse, C., Thisse, B., 2008. High-resolution in situ hybridization to whole-mount zebrafish embryos. Nat. Protoc. 3, 59-69.

Tsutsui, K., 2009. A new key neurohormone controlling reproduction, gonadotropin-inhibitory hormone $(\mathrm{GnIH})$ : Biosynthesis, mode of action and functional significance. Progr. Neurobiol. 88, 76-88.

Tsutsui, K., Ubuka, T., 2016. GnIH control of feeding and reproductive behaviors Front. Endocrinol. 7, 170.

Tsutsui, K., Saigoh, E., Ukena, K., Teranishi, H., Fujisawa, Y., Kikuchi, M., Ishii, S., Sharp, J.P., 2000. A novel avian hypothalamic peptide inhibiting gonadotropin release. Biochem. Biophys. Res. Co. 275, 661-667.

Tsutsui, K., Ubuka, T., Bentley, G.E., Kriegsfeld, L.J., 2012. Gonadotropin-inhibitory hormone (GnIH): discovery, progress and prospect. Gen. Comp. Endocrinol. 177, 305-314.

Vischer, H.F., Teves, A.C.C., Ackermans, J.C.M., van Dijk, W., Schulz, R.W., Bogerd, J., 2003. Cloning and spatiotemporal expression of the follicle-stimulating hormone beta subunit complementary DNA in the African catfish (Clarias gariepinus). Biol. Reprod. 68, 1324-1332.

Volkoff, H., Peter, R.E., 1999. Actions of two forms of gonadotropin releasing hormone and a GnRH antagonist on spawning behavior of the goldfish Carassius auratus. Gen. Comp. Endocrinol. 116, 347-355.

Wang, Y., Ge, W., 2004. Developmental profiles of activin beta A, beta B, and follistatin expression in the zebrafish ovary: evidence for their differential roles during sexual maturation and ovulatory cycle. Biol. Reprod. 71, 2056-2064.

White, R.B., Fernald, R.D., 1998. Genomic structure and expression sites of three gonadotropin-releasing hormone genes in one species. Gen. Comp. Endocrinol. 
$112,17-25$

Wirsig-Wiechmann, C.R., Jennes, L. 1993. Gonadotropin-Releasing-Hormone agonist binding in tiger salamander nasal cavity. Neurosci. Lett. 160, 201-204.

Wirsig-Wiechmann, C.R., Wiechmann, A.F., 2002. Vole retina is a target for gonadotropin-releasing hormone. Brain Res. 950, 210-217.

Xia, W., Smith, O., Zmora, N., Xu, S., Zohar, Y., 2014. Comprehensive analysis of GnRH2 neuronal projections in zebrafish. Sci. Rep. 4, 3676.
Zhang, W., Delay, R.J., 2007. Gonadotropin-releasing hormone modulates voltageactivated sodium current and odor responses in Necturus maculosus olfactory sensory neurons. J. Neurosci. Res. 85, 1656-1667.

Zhang, Y., Li, S., Liu, Y., Lu, D., Chen, H., Huang, X., Liu, X., Meng, Z., Lin, H., Cheng, C.H., 2010. Structural diversity of the $\mathrm{GnIH} / \mathrm{GnIH}$ receptor system in teleost: its involvement in early development and the negative control of $\mathrm{LH}$ release. Peptides 31, 1034-1043. 